\title{
Life Challenges of Overseas Filipino Workers
}

\author{
Alvin Gino M. Bautista, Vladimir T. Tamayo \\ Nueva Ecija University of Science and Technology, Cabanatuan City, Philippines \\ Email:agmbautista@yahoo.com
}

How to cite this paper: Bautista, A.G.M. and Tamayo, V.T. (2020) Life Challenges of Overseas Filipino Workers. Open Access Library Journal, 7: e6854. https://doi.org/10.4236/oalib.1106854

Received: September 22, 2020

Accepted: October 16, 2020

Published: October 19, 2020

Copyright (c) 2020 by author(s) and Open Access Library Inc.

This work is licensed under the Creative Commons Attribution International License (CC BY 4.0).

http://creativecommons.org/licenses/by/4.0/

Open Access

\begin{abstract}
Overseas Filipino Workers (OFWs) have been hailed by the Philippine government as "New Heroes" (Uy-Tioco, 2007) [1]. Having big houses, farms, cars, jewelry, and other signs of richness are common to many Overseas Filipino Workers (OFW) who are employed in different parts of the world. Working as an OFW is not always perfect as what is expected. The truth is that, they are also facing different challenges aside from leaving their families in the Philippines to have a better future. Communication, finances, and life and work environment are only some of those challenges they encounter. This research was made to evaluate the life challenges of selected overseas migrant workers. The 850 selected OFWs all around the world were the respondents of this study. The generality of this current study would be a great contribution to the huge knowledge concerning the challenges faced by Overseas Filipino Workers. The results of this study could be extremely significant and beneficial specifically to the following: Overseas Filipino Workers. The outcome of this research study will definitely produce essential information about the life challenges of every Overseas Filipino Worker, which might be a great support to the respondents in understanding themselves and their fellow OFWs who are also facing the same scenarios. Through the assistance of the recommendations of the researchers, it can also help them lessen their problems like in finances, homesickness or job burnout, "job burnout is an uncomfortable and unhealthy disorder that would like to improve for both individuals and organizations" (K. E. Santos, 2020) [2], and be able to know what to do and who can talk to in case that they feel problematic while they are miles away from home. Families of the Overseas Filipino Workers: The results of this study will help them understand their family member's situation while working abroad and appreciate their efforts in supporting their families. SSS, PhilHealth, POEA, and OWWA: The results of this study will help these agencies strengthen their services for the welfare, security, and benefits of the OFWs. Future Researchers: This will also be useful to the future and aspiring researchers to plan and create pertinent results to their studies similar to this current study. The researchers used a set of survey
\end{abstract}


questionnaires in gathering pertinent data. The questionnaires were disseminated via an online Google survey form sent to the respondents. After all the data needed were gathered, the frequencies of answers in each question were tallied and their percentage and weighted mean were obtained. It was concluded that Overseas Filipino Workers were facing different challenges while doing their respective job abroad. However, they can assure that the Philippine government supports and protects them even they were not in the Philippines.

\section{Subject Areas}

Human Resource Management, Labor Economics

\section{Keywords}

Overseas Filipino Workers, Life Challenges, Communication, Finances, Work Environment

\section{Introduction}

"Modern Day Heroes" is a great title tagged to all Overseas Filipino Workers (OFW) around the world. They are heroes who left their families and beloved country just to earn a better income to support their family and loved ones.

Aside from higher salary, to send their children to the school, to have small properties or investments, and to work in a greener pasture are the most common and simple reasons why OFWs choose to work abroad. As a result, many of them have 3-story houses, huge farmlands, cars, the latest gadget; their children were studying in an expensive private school, and many more extravagant livings. However, the money they invested in it caused them hard work, patience and problems before achieving these dreams.

There are almost 11 million Overseas Filipino Workers all over the world. "It is the largest global diaspora of migrant labor next to Mexico" (E. San Juan Jr, 2016) [3]. Name a country and there is a Filipino in it who would greet "hi", "hello", and "mabuhay". Many people in the Philippines believe that being a migrant worker is a good opportunity to uplift the life of whoever tried it, but the researchers as both former OFWs from Singapore and Japan were quite neutral about this idea. Some of them were not fortunate in finding a good job, a better salary, a happy work environment, and a contented family living in the Philippines.

With these aforementioned statements, the problem which the researchers wish to study is about the challenges that the Overseas Filipino Workers are facing in their everyday living outside the Philippines in terms of communication, finances, and life and work environment.

\section{Objectives of the Study}

Having a greener pasture is the number one reason why many Filipinos leave 
their families in the Philippines and work abroad. However, everyone is not living a fairy tale life wherein everything is under control. Every positive dream has connecting risks and challenges before reaching it. This research was made to identify the life challenges of every Filipino working abroad and to determine the problems they are facing from time to time.

Specifically, it sought to answer the following questions:

1) How may the profile of the Overseas Filipino Workers be described in terms of:

a) age;

b) sex;

c) civil status;

d) country of work;

e) number of years abroad;

f) types of work; and

g) monthly income?

2) How may the life of Overseas Filipino Workers be described in terms of:

a) communication;

b) finances; and

c) life and work environment?

3) What are the implications of the study?

\section{Methodology}

The researchers employed the Descriptive survey method of research. Descriptive research design defines understands, examines, and relates data and events. It intends to define systematically each event, condition of the area of interest correctly, and accurately. It includes observations, surveys, interviews, and standardized tests.

The study wishes to find out and describe the present profile of the selected Overseas Filipino Workers who are currently working in different countries around the world. This descriptive method was used in assessing the life challenges of every respondent in terms of communication, finances, life and work environment, and the top 3 challenges that the respondents were facing while they are working outside the Philippines.

This study used 850 respondents, which consisted of Overseas Filipino Workers in different countries all over the world. They were randomly selected to answer the survey questionnaire via Google survey form.

The researchers constructed the questionnaire after understanding the current scenario in the life of OFWs and decided to come up with a reliable instrument in the form of a questionnaire, and casual interviews. Brainstorming between the researchers who were also former OFWs was done to come up with the best questions that will suit to the respondent's experiences. The questionnaires were reviewed according to the suggestions of the researchers for the improvement of the instrument. The distribution of the questionnaires was done via Google sur- 
vey form. Google survey form is the most convenient tool to collect data especially to the respondents who were far away from the researcher. The data gathered through questionnaires were used only for the study and treated with supreme privacy.

The researchers measured the reliability and validity of the instrument by sending the questionnaires to the individual for trial. Scouting was also done to ensure that the respondents are true and real OFW. This was done by investigating the social media profile of the respondents, asking their online friends, relatives, and looking for pictures that support their true work and whereabouts.

After all the data needed were gathered, the frequencies of answers in each question were tallied and their percentage was obtained. The frequency, percentage, weighted mean, and mode of their answers were calculated in order to obtain its verbal description.

The hereunder scale with its corresponding verbal description was used as a guide in interpreting the responses to the items. Table 1 shows the scoring method.

\section{Results and Discussion}

According to the results of the online survey conducted with the 850 Overseas Filipino Workers as respondents, the following outcomes were:

It was noted that the youngest respondents were 19 years old and the oldest was 66 years old. The mode of the ages of the respondent was 28 years old. Fifty-four (54) out of 850 respondents were at the said age and it represents $6 \%$ of the total respondents.

The majority of the respondents were female while the minority were male. It is composed of 588 and 262 respondents respectively out of the 850 total respondents. In form of percentage, it represents $69 \%$ and $31 \%$ for female and male respondents respectively.

According to the survey conducted, most of the respondents were married. It represents 403 or $47 \%$ of the total number of respondents, followed by single which is 371 or $44 \%$, then the respondents who were separated which is 50 or $6 \%$ of the total 850 respondents.

Table 2 shows the country/area of work of the respondents. Based on the survey conducted, the United Arab Emirates has the greatest number of respondents with 171 or $20 \%$ out of 850 total number of the respondents. Kingdom of Saudi Arabia was the second in the list which has 125 or $15 \%$, and on the third

Table 1. Scoring method.

\begin{tabular}{ccc}
\hline Scale & Weight & Verbal description \\
\hline 4 & $3.26-4.00$ & Always \\
3 & $2.51-3.25$ & Often \\
2 & $1.76-2.50$ & Sometimes \\
1 & $1.00-1.75$ & Never \\
\hline
\end{tabular}


Table 2. Country/area of works of the respondents.

\begin{tabular}{ccccccccc}
\hline $\begin{array}{c}\text { Country/area } \\
\text { of work }\end{array}$ & $\mathbf{f}$ & $\%$ & Country of work & $\mathbf{f}$ & $\%$ & Country of work & $\mathbf{f}$ & $\%$ \\
\hline UAE & 171 & $20 \%$ & Korea & 12 & $1 \%$ & Germany & 3 & $0 \%$ \\
Saudi Arabia & 125 & $15 \%$ & Bahrain & 11 & $1 \%$ & Egypt & 3 & $0 \%$ \\
Taiwan (China) & 100 & $12 \%$ & Thailand & 10 & $1 \%$ & Spain & 2 & $0 \%$ \\
Hong Kong & 79 & $9 \%$ & Israel & 9 & $1 \%$ & Tahiti & 2 & $0 \%$ \\
(China) & 47 & $6 \%$ & United Kingdom & 6 & $1 \%$ & Cyprus & 2 & $0 \%$ \\
Qatar & 36 & $4 \%$ & Russia & 6 & $1 \%$ & Brunei & 2 & $0 \%$ \\
Japan & 31 & $4 \%$ & New Zealand & 6 & $1 \%$ & Switzerland & 1 & $0 \%$ \\
USA & 31 & $4 \%$ & China & 6 & $1 \%$ & Sri Lanka & 1 & $0 \%$ \\
Kuwait & 29 & $3 \%$ & Norway & 4 & $0 \%$ & Lebanon & 1 & $0 \%$ \\
Singapore & 23 & $3 \%$ & Marianas Is. & 4 & $0 \%$ & Laos & 1 & $0 \%$ \\
Canada & 16 & $2 \%$ & Turkey & 3 & $0 \%$ & Jordan & 1 & $0 \%$ \\
Seafarer & 15 & $2 \%$ & Sint Maarten & 3 & $0 \%$ & Denmark & 1 & $0 \%$ \\
Macau & 13 & $2 \%$ & Myanmar & 3 & $0 \%$ & Bahamas & 1 & $0 \%$ \\
Australia & 12 & $1 \%$ & Italy & 3 & $0 \%$ & Iceland & 1 & $0 \%$ \\
Oman & 12 & $1 \%$ & Hawaii & 3 & $0 \%$ & Total & 850 & $100 \%$ \\
Malaysia & 12 & & & & &
\end{tabular}

spot is Taiwan (China) which has 100 or $12 \%$ out of the 850 -total number of respondents.

The 330 or $39 \%$ of the total number of respondents have a monthly salary of 20,001 - 40,000 pesos, followed by Overseas Filipino Workers who have a salary of $0-20,000$ pesos which represents the 181 or $21 \%$ respondents. Then, 123 or $14 \%$ of the total number of respondents have a salary of $40,001-60,000$ pesos.

Table 3 shows the responses of the Overseas Filipino Workers in communication as a factor that challenges their life abroad. The statement "I clarify when I did not totally understand the instructions or what is being said to me" got the highest weighted mean of 3.41 with a verbal description of "Often", and the statement "I am having difficulty communicating with citizens and other foreigners" got the lowest weighted mean of 2.27 with a verbal description of "Sometimes".

Table 4 shows the responses of the respondents in finances as a factor that challenges them in their everyday life outside the Philippines. The statement "I have part-time jobs and overtime works as other sources of income" garnered the lowest weighted mean of 2.31 with a verbal description of "Often". On the contrary, the statement "I have part-time jobs and overtime works as another source of income" garnered the highest weighted mean of 3.63 which has a verbal description of "Always".

Table 5 represents the response of the Overseas Filipino Migrant Workers in life and work environment as a factor that challenges their life abroad. Thus, the statement "I maintain a good relationship with my fellowmen" obtained the highest weighted mean of 3.70 which has a verbal description of "Often" while the statement "I am having problems with my co-workers" obtained the lowest weighted mean of 2.15 with a verbal description of "Sometimes". 
Table 3. Communication.

\begin{tabular}{lcc}
\hline \multicolumn{1}{c}{ Statements } & WM & VD \\
\hline I am having difficulty communicating with citizens and other foreigners. & 2.27 & Sometimes \\
I greet and show interest when meeting foreigners without hesitation. & 3.10 & Often \\
I use body language and gestures as a way of better communication. & 2.82 & Often \\
I use simple words to make others understand me. & 3.28 & Always \\
I clarify when I did not totally understand the instructions or what is being \\
said to me.
\end{tabular}

Table 4. Finances.

\begin{tabular}{llc}
\hline \multicolumn{1}{c}{ Statement } & WM & VD \\
\hline I am able to send money to my family. & 3.63 & Always \\
I save money monthly from my salary. & 2.89 & Often \\
I invest in properties, stocks, insurance, and other investments. & 2.41 & Sometimes \\
I am able to contribute to PhilHealth, SSS, and others. & 2.73 & Often \\
I have part-time jobs and overtime works as another source of income. & 2.31 Sometimes
\end{tabular}

Table 5. Life and work environment.

\begin{tabular}{lll}
\hline \multicolumn{1}{c}{ Statement } & WM & VD \\
\hline $\begin{array}{l}\text { I feel that my employer is concerned about my status as a foreign worker } \\
\text { from the Philippines. }\end{array}$ & 3.28 & Always \\
I am having problems with my co-workers. & 2.15 & Sometimes \\
I feel quitting my job and go back to the Philippines. & 2.29 & Sometimes \\
I maintain a good relationship with my fellowmen. & 3.70 & Always \\
I still enjoy leisure time and recreation despite busy work and schedule. & 3.10 & Often \\
\hline
\end{tabular}

Table 6 shows the top 10 challenges that the respondents are facing abroad. Based on the survey conducted, homesickness got the highest score on the list, followed by salary, then challenges with their employer, and the last is their fellowmen.

\section{Conclusions}

Based on the findings of the study, the following conclusions were drawn:

1) The mode of the ages of the respondent was 28 years old. It is also concluded that females dominate the numbers of respondents, and most of them were married. It is also assumed that many of these married female respondents were mothers who left their young children just to earn income outside the Philippines. According to Karen Ng, 2019 [4] "growing up away from your mom comes with a long list of pros and cons. On one hand, we understand that they have their reasons for leaving us, but we just can't help but desperately wish that things were different. Mothers shape us in a way that only they can so beyond a doubt, their absence affects us as much". Middle East Asia countries were the greatest number of Overseas Filipino Workers which include the United Arab 
Table 6. Top 10 challenges of Overseas Filipino Workers.

\begin{tabular}{ccc}
\hline \multicolumn{2}{c}{ Top 10 Challenges of Overseas } & Filipino Workers \\
\hline Problem & f & $\%$ \\
\hline Homesickness & 597 & $70.20 \%$ \\
Salary & 300 & $35.30 \%$ \\
Employer & 282 & $33.20 \%$ \\
Savings & 267 & $31.40 \%$ \\
Language Barrier & 263 & $30.90 \%$ \\
Co-Workers & 237 & $27.90 \%$ \\
Work Load & 203 & $23.90 \%$ \\
Climate & 154 & $18.10 \%$ \\
Housing and Lodging & 102 & $12 \%$ \\
Transportation & 27 & $3.20 \%$ \\
Fellowmen & 25 & $2.90 \%$ \\
\hline
\end{tabular}

Emirates on the top of the list particularly in Dubai, and Abu Dhabi. Saudi Arabia was on the second spot, while Qatar ranked number 5, Kuwait was on the 8 spot, and Oman was number 14 on the list. With this, the researchers conclude that these countries in Middle East Asia have a lot of works to be offered for migrant workers.

2) In terms of communication, OFWs are having difficulty in dealing with foreigners because of language barrier so they opt to communicate in English and or by using body language. According to the study of Dr. Rhodora R. Jugo, 2020 [5], "Speaking activities are the primarily source of high anxiety". With regard to finances, sending money to their families and loved ones was their top priority. Finally, on the life and work environment aspect, it was noted that most of them were in good condition because the Philippine government through the Philippines Overseas Employment Administration (POEA), Overseas Worker Welfare Administration (OWWA), and other Non-Government Organizations (NGO) support and protect the life of the Filipino workers abroad.

3) The implications of the study are the following:

English as Filipinos' second language helped the respondents a lot because communicating with other foreigners was not a hindrance or major challenge. Aside from English proficiency, they can deliver what they want to say through the use of gestures and simple words for them to be easily understood. According to Tomas W. Adams, 1998 [6] "Previous research has established that native speakers modify their speech when addressing the non-native speakers. This phenomenon, known as foreigner talk, has been shown to assist comprehension, which in turn provides a condition that is conducive to second language acquisition".

Female Overseas Filipino Workers are sending a greater share of remittance compared to their male counterparts to support children's education, despite the global gender pay gap (Philstar.com, 2018) [7]. Most of them have sav- 
ings but it was noted that not all of them have an investment in properties, insurance, stocks, as well as payment of a contribution in SSS, PhilHealth, and so on.

The Government has the assurance of protecting and promoting the welfare and well-being of OFWs as one of its top priorities as an appreciation for all their hardships and sacrifices. This nation always recognizes their invaluable contribution to nation-building, and continues to craft policies and implement programs that will respond to their needs. As a proof, the Chief Executive [President Rodrigo Roa Duterte] said during the conferment of the 2018 Presidential Awards for Filipino Individuals and Organizations Overseas (PAFIOO) and the Model OFW Family of the Year Awards (MOFYA). (PCOO, 2018) [8]. "As an appreciation for all your hardships, you have my assurance that the protection and promotion of your welfare and well-being will remain as one of this administration's top priorities. This nation will always recognize your invaluable contribution to nation-building, and this administration will continue to craft policies and implement programs that will respond to your needs and protect your rights".

\section{Recommendations}

In the light of the above conclusions, the following recommendations are offered:

1) OFWs who are in the senior stage or 60 years old and above may retire from their current job. They may stay in the country where they are working and try to apply for permanent status. If this will not be granted because of their age, they may go back to the Philippines and enjoy their life here to the fullest.

2) Frequent communication with their families especially with their children must remain intact, for distance should be the reason for broken families. Also, they may always remember one of the main motives why they chose to go and work abroad, and this is to make their families in good condition not only financially, but also emotionally and mentally through continuously performing their role as parents even in a far-away land.

3) Filipinos must obey other countries' laws, policies and regulations. They may also try to understand and adopt the culture and behavior of the locals who are living there. It might be not easy, but in a long run, it will be beneficial for them as foreign workers to avoid cultural problems and differences.

4) Body language and gestures in communicating with other foreigners may be used. Grammar is important in business and professional communication, but in casual or informal talks, body language and gestures were most vital for the speakers and for the receivers to easily comprehend what they want to share.

5) OFWs may entrust their savings in different investments such as in properties, stocks, insurance, and the likes. Continuous payment of their contribution to PhilHealth and SSS must be considered because it can really help them in the future when they retire from work and go back to the Philippines. 
6) The Philippine Government must continue crafting policies and implement programs that will respond to the needs of OFWs.

7) Families of OFWs need to be more understanding of the choice that their loved ones make in working abroad. In fact, their loved ones are selfless persons because they place their families over and above them as their priority. Their families' happiness and future are more important to them.

8) Future researchers may replicate this study for deeper understanding of the life challenges of OFWs.

\section{Acknowledgements}

The researchers wish to extend their gratitude to the people who have contributed much in the fulfillment of this study especially the Overseas Filipino Workers and their families, who have given their unparalleled cooperation and support. This study is dedicated to all of the unsung heroes for their selflessness, sacrifices, hard work and patience to give their loved ones a better life, and for continuously raising the Philippine flag all over the world.

\section{Conflicts of Interest}

The authors declare no conflicts of interest regarding the publication of this paper.

\section{References}

[1] Uy-Tioco, C. (2007) Overseas Filipino Workers and Text Messaging: Reinventing Transnational Mothering. Journal of Media \& Cultural Studies, 21, 253-265. https://doi.org/10.1080/10304310701269081

[2] Santos, K.E.S. and De Jesus, C.D. (2020) Job Burnout of Contractual Workers in Nueva Ecija. Open Access Library Journal, 7, e6113. https://doi.org/10.4236/oalib.1106113

[3] San Juan, E. (2009) Overseas Filipino Workers: The Making of an Asian-Pacific Diaspora. The Global South, 3, 99-129.

http://www.jstor.org/stable/10.2979/gso.2009.3.2.99 https://doi.org/10.2979/gso.2009.3.2.99

[4] Ng, K. (2019) In Focus: Things Those Who Grew Up with an OFW Mom Will Understand, ABS-CBN Lifestyle.

[5] Jugo, R.R. (2020) Language Anxiety in Focus: The Case of Filipino Undergraduate Teacher Education Learners. Education Research International, 2020, Article ID: 7049837. https://doi.org/10.1155/2020/7049837

[6] Adams, T.W. (1998) Gesture in Foreigner Talk. University of Pennsylvania, ProQuest Dissertations Publishing, Ann Arbor, MI, USA.

[7] Philstar.com (2018) Study: Female OFWs Send More Money than Men; Education Is Top Priority, Health and Family. Philstar Global.

[8] Gov.PH (2018) President Duterte Vows to Protect OFWs. Republic of the Philippines, Presidential Communication Operations Office, Malacanang Manila. 